\title{
Oligoetherols and polyurethane foams obtained from melamine diborate
}

\author{
${\text { Ewelina } \text { Chmiel }^{1} \text { • Jacek Lubczak }}^{1}$ (I)
}

Received: 20 August 2016 / Accepted: 9 May 2017 /Published online: 23 May 2017

(C) The Author(s) 2017. This article is an open access publication

\begin{abstract}
The method of synthesis of oligoetherols with 1,3,5-triazine ring and boron was established. The obtained oligoetherol is suitablse to obtaining polyurethane foams (PUFs) of enhanced thermal resistance and diminished flammability. The obtained PUFs can stand long term thermal exposure at $175{ }^{\circ} \mathrm{C}$. The PUFs annealed at 150 and $175{ }^{\circ} \mathrm{C}$ showed improved compressive strength in comparison with not exposed to heating.
\end{abstract}

Keywords Heteroatom containing-polymer · Synthesis · Structure $\cdot$ Polyurethane foams $\cdot$ Properties

\section{Introduction}

Introduction of thermally stable 1,3,5-triazine, perhydro1,3,5-triazine and purine rings into oligoetherols suitable to obtain polyurethane foams (PUFs) resulted in formation of PUFs of enhanced thermal resistance [1]. The cheap source for such application is melamine (MEL), which contains 1,3,5,-triazine ring. Hydroxyalkylation of MEL with alkylene carbonates resulted in formation of desired oligoetherols [2] according to the following scheme:<smiles>Nc1nc(N)nc(N)n1</smiles>

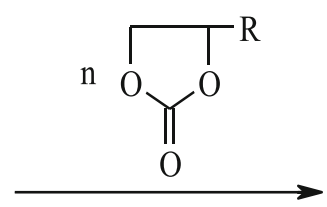

where: $\mathrm{m}+\mathrm{p}+\mathrm{q}+\mathrm{x}+\mathrm{y}+\mathrm{z}=\mathrm{n}$

The PUFs obtained from them can be applied as thermal isolators for pipes for transmission of heating media or

Jacek Lubczak

jml@ prz.edu.pl

1 Department of Organic Chemistry, Faculty of Chemistry, Rzeszów University of Technology, Al. Powstańców Warszawy 6, 35-959 Rzeszów, Poland isolators for cistern transporting liquid sulfur. Generally PUFs have low heat capacity and therefore are good heat insulator, which application can be spread provided their flame resistant is increased. Obtained PUFs with 1,3,5-triazine ring themselves are flammable which makes them useless as thermal insulators at high temperatures. Recently boron and its compounds are tested as flame retardants. The products of reaction between boric acid and diols, derivatives of urea or oxiranes like glycerine epichlorhydrin were reported as flame 
retardants, when introduced into composite at foaming step [3-8]. Oligoetherols containing azacyclic rings and boron atoms were obtained from hydroxyethyl derivatives of isocyanuric acid, uric acid and melamine with boric acid, and then with hydroxyalkylating agents like oxiranes and alkylene carbonates. Those oligoetherols upon reaction with water and isocyanates gave self-distinguishing or lowered flammability PUFs in comparison with classic ones. However the synthetic protocol is a multistep process: cyanuric chloride was reacted with diethanolamine to obtain hydroxyalkyl derivatives, which were ester:ified with boric acid to get hydroesters of boric acid with 1,3,5-triazine ring, which was later hydroxyalkylated with alkylene carbonates into desired oligoetherols according to the scheme [9]:<smiles>OCCNCCO</smiles><smiles>OCCN(CCO)c1nc(N(CCO)CCO)nc(N(CCO)CCO)n1</smiles>

N,N,N'N', N", N"-hexakis(2-hydroxyethyl)melamine (HHEM)

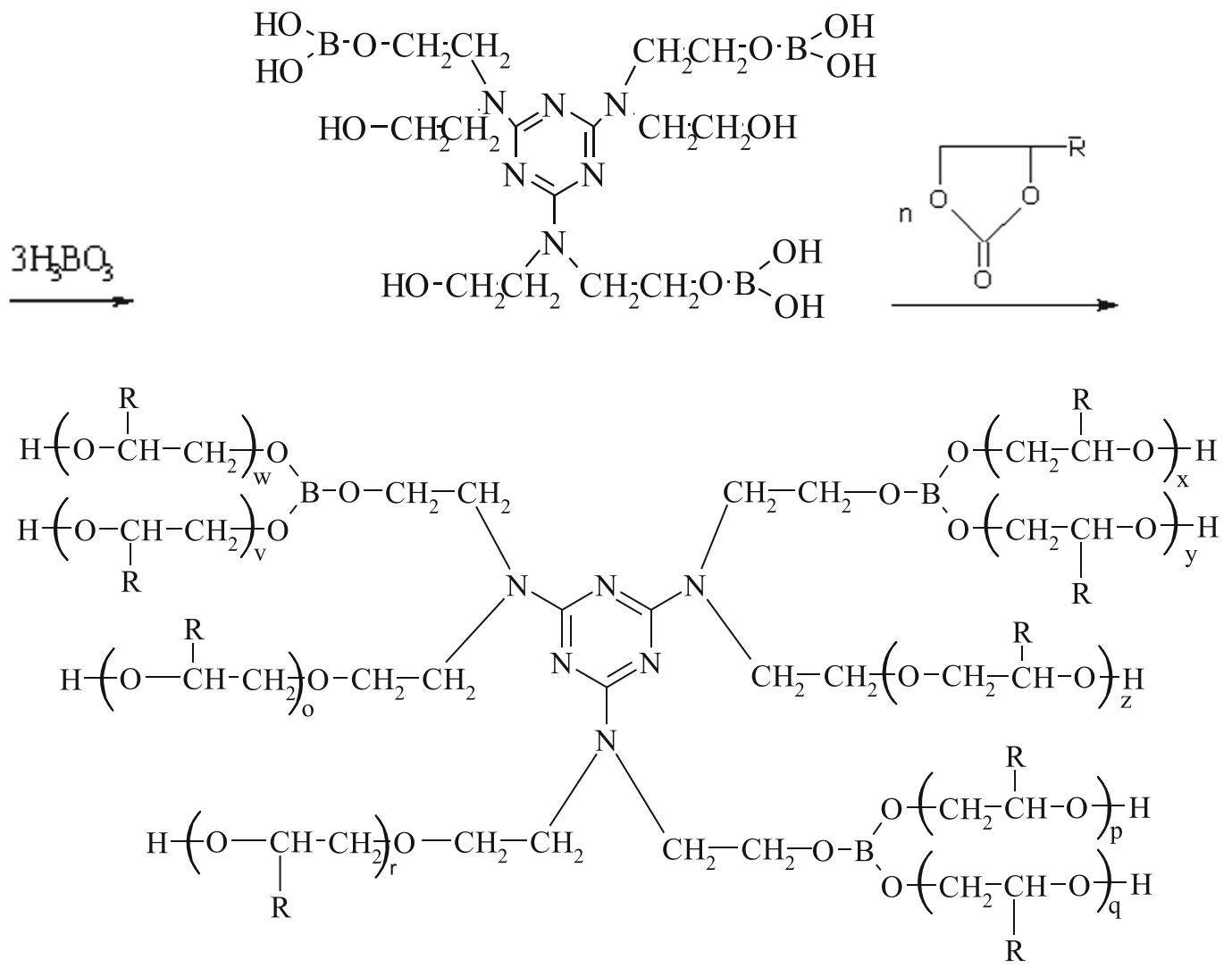

where: $\mathrm{R}=-\mathrm{H},-\mathrm{CH}_{3} ; \mathrm{x}+\mathrm{y}+\mathrm{z}+\mathrm{p}+\mathrm{q}+\mathrm{w}+\mathrm{v}+\mathrm{o}+\mathrm{r}=\mathrm{n}$

Multistep reaction and the necessity of separation and purification of intermediated were the disadvantages of that approach [9]. Therefore we are searching for less laborious method leading to oligoetherols - suitable substrates for thermally resistant and incombustible PUFs. It seemed that melamine diborate (MDB) might serve as good candidate to synthesize such oligoetherols due to presence of 1,3,5-triazine ring and boron incorporated in it. 


\section{Experimental}

\section{Syntheses}

\section{Synthesis of melamine diborate (MDB)}

$50.4 \mathrm{~g}$ (0.4 mol) melamine (pure, Fluka, Buchs, Switzerland) was dissolved in $2400 \mathrm{~cm}^{3}$ hot water. $49.5 \mathrm{~g}(0.8 \mathrm{~mol})$ boric acid (pure, POCH, Poland) was dissolved in $400 \mathrm{~cm}^{3}$ water at $70{ }^{\circ} \mathrm{C}$. The solutions were mixed and cooled to room temperature with continuous stirring. MDB (MEL $\left.2 \mathrm{H}_{3} \mathrm{BO}_{3}\right)$ precipitated as white solid, which was filtered off, washed with water and air-dried. Yield 81\% [10].

\section{Syntheses of oligoetherols from melamine diborate and ethylene carbonates}

$81.0 \mathrm{~g}(0.32 \mathrm{~mol})$ of MDB, $619.5 \mathrm{~g}(7.04 \mathrm{~mol})$ of ethylene carbonate (EC, pure, Sigma-Aldrich, Germany) and $4.8 \mathrm{~g}$ $(0.03 \mathrm{~mol})$ of potassium carbonate (pure, $\mathrm{POCH}$, Poland) as catalyst were placed in three-necked $750 \mathrm{~cm}^{3}$ flask equipped with mechanical stirrer, reflux condenser and thermometer and heated to $170-180{ }^{\circ} \mathrm{C}$ for $10 \mathrm{~h}$. Dark-brown resin-like products were obtained. The progress of reaction was monitored by determination of unreacted alkylene carbonate.

\section{Analytical methods}

The progress of reaction between MDB and EC was monitored using barium hydroxide method described in [11]. The acid number (AN) of oligoetherols was determined by titration with $0.1 \mathrm{M}$ sodium hydroxide in presence of phenolphthalein. The hydroxyl number $(\mathrm{HN})$ was determined by acylation with acetic anhydride in xylene; the anhydride excess was then titrated off with $1.5 \mathrm{M} \mathrm{NaOH}$ in presence of phenolphthalein [12]. Elemental analysis for $\mathrm{C}, \mathrm{H}, \mathrm{N}$, were done with EA 1108, Carlo-Erba analyzer. The boron was determined by emission atomic spectrometry (ICP-OES VISTA-MPX spectrometer, Varian, USA with $10 \%$ accuracy). The ${ }^{1} \mathrm{H}-\mathrm{NMR}$ spectra of products were recorded at $500 \mathrm{MHz}$ Bruker UltraShield in DMSO- $\mathrm{d}_{6}$ with hexamethyldisiloxane as internal standard. IR spectra were registered on ALPHA FT-IR BRUKER spectrometer in $\mathrm{KBr}$ pellets or ATR technique. MALDI ToF (MatrixAssiated Laser Desorption Ionization Time of Flight) of oligoetherols were obtained on Voyager-Elite Perceptive Biosystems (US) mass spectrometer working at linear mode with delayed ion extraction, equipped with nitrogen laser working at $352 \mathrm{~nm}$. The method of laser desorption from gold matrix was applied. Therefore the observed peaks corresponded to the molecular ions plus $\mathrm{Au}$ and $\mathrm{K}^{+}$(from catalyst) ions. The samples were diluted with water to $0.5 \mathrm{mg} / \mathrm{cm}^{3}$.

In order to identify side products (glycols and polyglycols) formed in the reaction of MDB with EC and the compounds formed in consecutive reactions with $\mathrm{EC}$, the oligoetherols were separated chromatographically using cyklohexanone (cz.da. S.A. POCH, Gliwice, Poland) as internal standard. The gas chromatograph HP 4890A was used, equipped with HP-FFAP column of $30 \mathrm{~m}$ length, $0.53 \mathrm{~mm}$ diameter, $1.5 \mu \mathrm{m}$ film thickness and $220^{\circ} \mathrm{C}$ port temperature and temperature proRef: 50 $220^{\circ} \mathrm{C}$, with $20 \mathrm{deg} . / \mathrm{min}$ heating rate, the helium flow $18.3 \mathrm{~cm}^{3} /$ min, and $0.2 \mu \mathrm{dm}^{3}$ sample volume. Series of reference substances were used: ethylene glycol, diethylene glycol, triethylene glycol and tetraethylene glycol, (pure Aldrich, UK). The percentage of diols in products was determined based on calibration curves with the same internal standard using formula (3):

$\frac{S_{c d}}{S_{t}}=a \times\left(\frac{m_{c d}}{m_{t}}\right)+\mathrm{b}$

where:

$\mathrm{m}_{\mathrm{cd}}$, diol mass or consecutive product of its reaction with $\mathrm{m}_{\mathrm{t}} \quad$ alkylene carbonate and mass of standard, respectively,

$\mathrm{S}_{\mathrm{cd}}$, integrated peak area of diol or consecutive product

$\mathrm{S}_{\mathrm{t}} \quad$ and standard, respectively

$\mathrm{a}, \mathrm{b}$ experimental coefficients of calibration curves.

Mass of products obtained from EC or PC and water and mass of products of consecutive reactions between diols and alkylene carbonates were calculated from formula (3). The percentage of side products were calculated considering total sample mass $\left(m_{p}\right)$ according to formula (4):

$P_{c d}\left(\frac{m_{c d}}{m_{p}}\right) \times 100 \%$

\section{Physical properties of oligoetherols}

Refraction index, density, viscosity, and surface tension of oligoetherols were determined with Abbe refractometer, pycnometer, Höppler viscometer (typ BHZ, prod. Prüfgeratewerk, Germany) [13] and by the detaching ring method [14], respectively.

\section{Obtaining the polyurethane foams}

Foaming of oligoetherols was performed at $500 \mathrm{~cm}^{3}$ cups at temperature $20-25^{\circ} \mathrm{C}$. The foams were prepared from $10 \mathrm{~g}$ of oligoetherol, to which $0.23-0.31 \mathrm{~g}$ of surfactant (Silicon L-6900, pure, Momentive, USA), and 0.01-0.13 g g of triethylamine (pure, Fluka, Switzerland) as catalyst and water $(6 \%)$ as blowing agent were added. After the homogenization the polymeric diphenylmethane $4,4^{\prime}$-diisocyanate was added. The commercial isocyanate containing $30 \%$ of trifunctional isocyanates was used (Merck, Germany). Values of the $\mathrm{NCO} / \mathrm{OH}$ ratio were 1.4. 
The mixture was vigorously stirred until creaming began. The samples for further studies were cut off the obtained foams.

\section{Properties of foams}

The apparent density [15], water uptake [16], dimensional stability [17] in $150{ }^{\circ} \mathrm{C}$ temperature, heat conductance coefficient (IZOMET 2104, Slovakia), and compressive strength [18] of PUFs with flame retardants were measured. Thermal resistance of modified foams was determined both by static and dynamic methods. In static method the foams were heated at 150, 175, and $200{ }^{\circ} \mathrm{C}$ with continuous measurement of mass loss and determination of mechanical properties before and after heat exposure. In dynamic method thermal analyses of foams were performed in ceramic crucible at $20-600^{\circ} \mathrm{C}$ temperature range, about $100 \mathrm{mg}$ sample, under air atmosphere with Thermobalance TGA/DSC 1 derivatograph, Mettler, with $10^{\circ} \mathrm{C} / \mathrm{min}$ heating rate. Flammability of foams was determined by oxygen index and horizontal test according to norm [19] as follows: the foam samples $(150 \times 50 \times 13 \mathrm{~mm})$ were weighed, located on horizontal support (wire net of $200 \times 80 \mathrm{~mm}$ dimensions) and the line was marked at the distance of $25 \mathrm{~mm}$ from edge. The sample was set on fire from the opposite edge using Bunsen burner with the blue flame of $38 \mathrm{~mm}$ height for $60 \mathrm{~s}$. Then the burner was removed and time of free burning of foam reaching marked line or cease of flame was measured by stopwatch. After that the samples were weighed again. The rate of burning was calculated according to the expression:

$v=\frac{125}{t_{b}}$

if the sample was burned totally, or using equation:

$v=\frac{L_{e}}{t_{e}}$

if the sample ceased burning, where:

$L_{e} \quad$ the length of burned fragment, measured as the difference 150 minus the length of unburned fragment

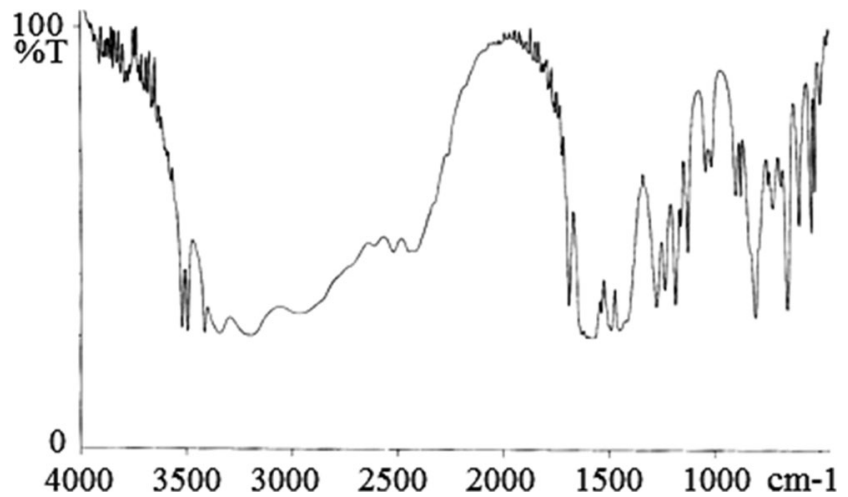

Fig. 1 IR spectrum of MDB

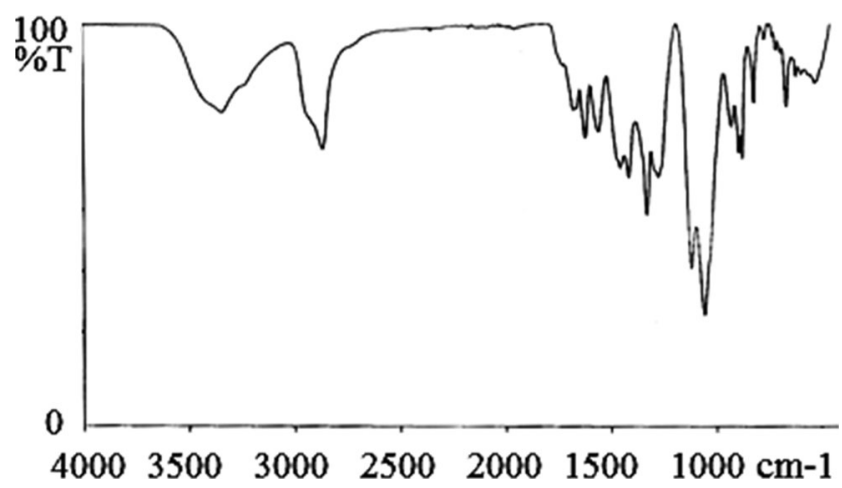

Fig. 2 IR spectrum of oligoetherol

(in $\mathrm{mm}$ ). According to norms, if the burned fragment has the $125 \mathrm{~mm}$ length, the foam is considered as flammable.

$t_{b}$, the time of propagation of flame measured at the

$t_{e} \quad$ distance between starting mark up to the end mark or as the time of flame cease.

The mass loss $\Delta m$ after burning was calculated from the formula:

$\Delta m=\frac{m_{o}-m}{m_{o}} \cdot 100 \%$

where:

$m_{o}$ and $m$ mean the sample mass before and after burning, respectively.

The surface morphology of PUFs was photo-recorded with Malvern's MORPHOLOGI G3 apparatus with 123 (zoom 2.5) and 247 (zoom 5.0) enhancement lens.

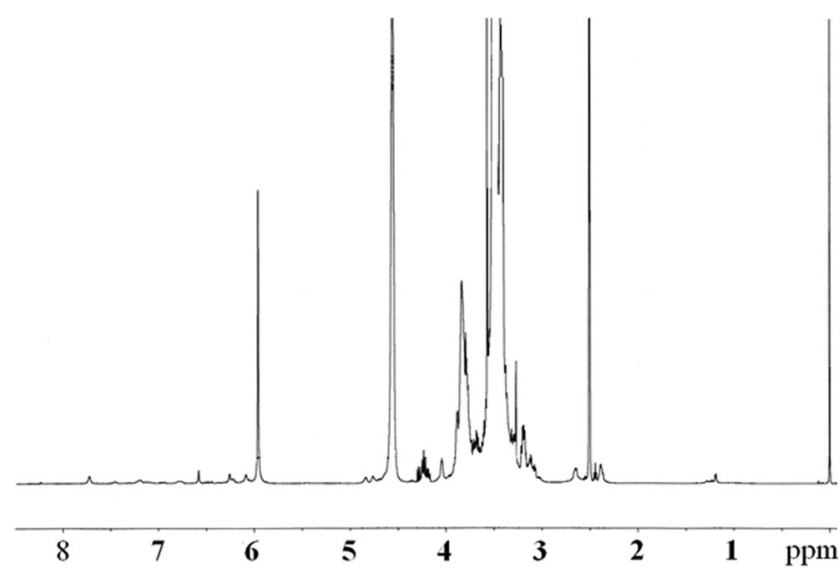

Fig. $3{ }^{1} \mathrm{H}-\mathrm{NMR}$ spectrum of oligoetherol 
Table 1 Interpretation of MALDI-ToF spectrum of oligoetherol

\begin{tabular}{|c|c|c|c|c|}
\hline Entry & Signal position $\mathrm{m} / \mathrm{z}$ & $\begin{array}{l}\text { Relative intensity } \\
\text { of signal [\%] }\end{array}$ & The molecular ion structure & $\begin{array}{l}\text { Calc. molecular } \\
\text { weight }[\mathrm{g} / \mathrm{mol}]\end{array}$ \\
\hline 1 & 87.052 & 4.7 & $\mathrm{H}_{3} \mathrm{BO}_{3}+\mathrm{OE}-\mathrm{H}_{2} \mathrm{O}-\mathrm{H}^{+}$ & 86.860 \\
\hline 2 & 89.006 & 4.9 & $\mathrm{EC}+\mathrm{H}^{+}$ & 89.120 \\
\hline \multirow[t]{2}{*}{3} & 127.089 & 28.1 & $\mathrm{MEL}+\mathrm{H}^{+}$ & 127.131 \\
\hline & & & $\mathrm{H}_{3} \mathrm{BO}_{3}+\mathrm{OE}-\mathrm{H}_{2} \mathrm{O}+\mathrm{K}^{+}$ & 126.966 \\
\hline \multirow[t]{2}{*}{4} & 154.058 & 26.0 & $\mathrm{H}_{3} \mathrm{BO}_{3}+2 \mathrm{OE}-\mathrm{H}_{2} \mathrm{O}+\mathrm{Na}^{+}$ & 154.908 \\
\hline & & & $\mathrm{MEL}+\mathrm{OE}-\mathrm{H}_{2} \mathrm{O}+\mathrm{H}^{+}$ & 153.167 \\
\hline 5 & 173.130 & 18.8 & $\mathrm{H}_{3} \mathrm{BO}_{3}+2 \mathrm{OE}+\mathrm{Na}^{+}$ & 172.923 \\
\hline 6 & 175.101 & 7.4 & $\mathrm{H}_{3} \mathrm{BO}_{3}+3 \mathrm{OE}-\mathrm{H}_{2} \mathrm{O}$ & 175.970 \\
\hline \multirow[t]{3}{*}{7} & 189.076 & 69.1 & $\mathrm{MEL}+\mathrm{H}_{3} \mathrm{BO}_{3}+\mathrm{H}^{+}$ & 188.963 \\
\hline & & & $\mathrm{H}_{3} \mathrm{BO}_{3}+2 \mathrm{OE}+\mathrm{K}^{+}$ & 189.032 \\
\hline & & & $\mathrm{MEL}+\mathrm{OE}+\mathrm{H}_{2} \mathrm{O}+\mathrm{H}^{+}$ & 189.197 \\
\hline 8 & 195.129 & 11.8 & $\mathrm{H}_{3} \mathrm{BO}_{3}+3 \mathrm{OE}+\mathrm{H}^{+}$ & 194.993 \\
\hline 9 & 197.002 & 22.1 & $\mathrm{MEL}+2 \mathrm{OE}-\mathrm{H}_{2} \mathrm{O}+\mathrm{H}^{+}$ & 197.218 \\
\hline 10 & 198.131 & 58.6 & $\mathrm{H}_{3} \mathrm{BO}_{3}+3 \mathrm{OE}-\mathrm{H}_{2} \mathrm{O}+\mathrm{Na}^{+}$ & 198.959 \\
\hline 11 & 217.129 & 25.4 & $\mathrm{H}_{3} \mathrm{BO}_{3}+3 \mathrm{OE}+\mathrm{Na}^{+}$ & 216.974 \\
\hline 12 & 218.173 & 22.9 & $\mathrm{H}_{3} \mathrm{BO}_{3}+3 \mathrm{OE}+\mathrm{Na}^{+}+\mathrm{H}^{+}$ & 217.982 \\
\hline \multirow[t]{2}{*}{13} & 219.169 & 14.2 & $\mathrm{H}_{3} \mathrm{BO}_{3}+4 \mathrm{OE}-\mathrm{H}_{2} \mathrm{O}-\mathrm{H}^{+}$ & 219.013 \\
\hline & & & $\mathrm{MEL}+2 \mathrm{OE}+\mathrm{Na}^{+}$ & 219.230 \\
\hline 14 & 220.154 & 14.2 & $\mathrm{H}_{3} \mathrm{BO}_{3}+4 \mathrm{OE}-\mathrm{H}_{2} \mathrm{O}$ & 220.021 \\
\hline \multirow[t]{2}{*}{15} & 233.105 & 100.0 & $\mathrm{H}_{3} \mathrm{BO}_{3}+3 \mathrm{OE}+\mathrm{K}^{+}$ & 233.110 \\
\hline & & & $\mathrm{MEL}+2 \mathrm{OE}+\mathrm{H}_{2} \mathrm{O}+\mathrm{H}^{+}$ & 233.268 \\
\hline 16 & 239.199 & 6.8 & $\mathrm{H}_{3} \mathrm{BO}_{3}+4 \mathrm{OE}+\mathrm{H}^{+}$ & 239.078 \\
\hline \multirow[t]{2}{*}{17} & 242.184 & 79.8 & $\mathrm{H}_{3} \mathrm{BO}_{3}+4 \mathrm{OE}-\mathrm{H}_{2} \mathrm{O}+\mathrm{Na}^{+}$ & 243.010 \\
\hline & & & $\mathrm{MEL}+3 \mathrm{OE}-\mathrm{H}_{2} \mathrm{O}+\mathrm{H}^{+}$ & 241.269 \\
\hline 18 & 243.199 & 5.1 & $\mathrm{H}_{3} \mathrm{BO}_{3}+4 \mathrm{OE}-\mathrm{H}_{2} \mathrm{O}+\mathrm{Na}^{+}$ & 243.010 \\
\hline \multirow[t]{2}{*}{19} & 257.146 & 6.6 & $\mathrm{H}_{3} \mathrm{BO}_{3}+\mathrm{Au}-\mathrm{H}^{+}$ & 257.790 \\
\hline & & & $\mathrm{H}_{3} \mathrm{BO}_{3}+4 \mathrm{OE}+\mathrm{H}_{2} \mathrm{O}+\mathrm{H}^{+}$ & 257.059 \\
\hline 20 & 261.203 & 6.4 & $\mathrm{H}_{3} \mathrm{BO}_{3}+4 \mathrm{OE}+\mathrm{Na}^{+}$ & 261.025 \\
\hline 21 & 263.158 & 7.4 & $\mathrm{MEL}+3 \mathrm{OE}-\mathrm{H}_{2} \mathrm{O}+\mathrm{Na}^{+}$ & 263.250 \\
\hline 22 & 264.167 & 7.5 & $\mathrm{H}_{3} \mathrm{BO}_{3}+5 \mathrm{OE}-\mathrm{H}_{2} \mathrm{O}$ & 264.072 \\
\hline 23 & 266.205 & 8.1 & $\mathrm{H}_{3} \mathrm{BO}_{3}+5 \mathrm{OE}-\mathrm{H}_{2} \mathrm{O}+\mathrm{H}^{+}$ & 265.080 \\
\hline 24 & 277.103 & 32.7 & $\mathrm{H}_{3} \mathrm{BO}_{3}+4 \mathrm{OE}+\mathrm{K}^{+}$ & 277.134 \\
\hline \multirow[t]{2}{*}{25} & 286.197 & 83.4 & $\mathrm{H}_{3} \mathrm{BO}_{3}+\mathrm{OE}-\mathrm{H}_{2} \mathrm{O}+\mathrm{H}^{+}+\mathrm{Au}$ & 285.842 \\
\hline & & & $\mathrm{MEL}+4 \mathrm{OE}-\mathrm{H}_{2} \mathrm{O}+\mathrm{H}^{+}$ & 285.320 \\
\hline 26 & 287.160 & 5.8 & $\mathrm{H}_{3} \mathrm{BO}_{3}+5 \mathrm{OE}-\mathrm{H}_{2} \mathrm{O}+\mathrm{Na}^{+}$ & 287.061 \\
\hline \multirow[t]{2}{*}{27} & 301.111 & 6.8 & $\mathrm{H}_{3} \mathrm{BO}_{3}+5 \mathrm{OE}+\mathrm{H}_{2} \mathrm{O}+\mathrm{H}^{+}$ & 301.110 \\
\hline & & & $\mathrm{H}_{3} \mathrm{BO}_{3}+\mathrm{OE}+\mathrm{Au}$ & 302.849 \\
\hline 28 & 306.177 & 5.9 & $\mathrm{H}_{3} \mathrm{BO}_{3}+5 \mathrm{OE}+\mathrm{Na}^{+}$ & 305.076 \\
\hline 29 & 308.181 & 5.9 & $\mathrm{H}_{3} \mathrm{BO}_{3}+6 \mathrm{OE}-\mathrm{H}_{2} \mathrm{O}$ & 308.123 \\
\hline \multirow[t]{2}{*}{30} & 310.221 & 20.8 & $\mathrm{MDB}+\mathrm{OE}+\mathrm{H}_{2} \mathrm{O}-\mathrm{H}^{+}$ & 310.838 \\
\hline & & & $\mathrm{MEL}+5 \mathrm{OE}-2 \mathrm{H}_{2} \mathrm{O}$ & 310.348 \\
\hline \multirow[t]{2}{*}{31} & 321.124 & 8.6 & $\mathrm{H}_{3} \mathrm{BO}_{3}+\mathrm{OE}+\mathrm{H}_{2} \mathrm{O}+\mathrm{H}^{+}+\mathrm{Au}$ & 321.952 \\
\hline & & & $\mathrm{H}_{3} \mathrm{BO}_{3}+5 \mathrm{OE}+\mathrm{K}^{+}$ & 321.185 \\
\hline 32 & 330.207 & 71.8 & $\mathrm{MEL}+5 \mathrm{OE}-\mathrm{H}_{2} \mathrm{O}+\mathrm{H}^{+}$ & 329.371 \\
\hline 33 & 331.235 & 9.0 & $\mathrm{H}_{3} \mathrm{BO}_{3}+6 \mathrm{OE}-\mathrm{H}_{2} \mathrm{O}+\mathrm{Na}^{+}$ & 331.157 \\
\hline \multirow[t]{2}{*}{34} & 338.353 & 9.8 & $\mathrm{H}_{3} \mathrm{BO}_{3}+5 \mathrm{OE}+\mathrm{H}_{2} \mathrm{O}+\mathrm{K}^{+}$ & 339.200 \\
\hline & & & $\mathrm{MDB}+2 \mathrm{OE}$ & 337.810 \\
\hline 35 & 343.111 & 14.2 & $\mathrm{MEL}+4 \mathrm{OE}+\mathrm{H}_{2} \mathrm{O}+\mathrm{Na}^{+}$ & 343.331 \\
\hline
\end{tabular}


Table 1 (continued)

\begin{tabular}{|c|c|c|c|c|}
\hline Entry & Signal position $\mathrm{m} / \mathrm{z}$ & $\begin{array}{l}\text { Relative intensity } \\
\text { of signal [\%] }\end{array}$ & The molecular ion structure & $\begin{array}{l}\text { Calc. molecular } \\
\text { weight }[\mathrm{g} / \mathrm{mol}]\end{array}$ \\
\hline \multirow[t]{2}{*}{36} & \multirow[t]{2}{*}{354.240} & \multirow[t]{2}{*}{17.7} & $\mathrm{MEL}+6 \mathrm{OE}-2 \mathrm{H}_{2} \mathrm{O}$ & 354.399 \\
\hline & & & $\mathrm{H}_{3} \mathrm{BO}_{3}+7 \mathrm{OE}-\mathrm{H}_{2} \mathrm{O}+\mathrm{H}^{+}$ & 358.238 \\
\hline 37 & 374.252 & 40.9 & $\mathrm{MEL}+6 \mathrm{OE}-\mathrm{H}_{2} \mathrm{O}+\mathrm{H}^{+}$ & 373.422 \\
\hline 38 & 375.270 & 5.6 & $\mathrm{H}_{3} \mathrm{BO}_{3}+7 \mathrm{OE}-\mathrm{H}_{2} \mathrm{O}+\mathrm{Na}^{+}$ & 375.163 \\
\hline \multirow[t]{2}{*}{39} & \multirow[t]{2}{*}{387.121} & \multirow[t]{2}{*}{23.5} & $\mathrm{MEL}+5 \mathrm{OE}+\mathrm{H}_{2} \mathrm{O}+\mathrm{Na}^{+}$ & 387.382 \\
\hline & & & $\mathrm{MDB}+3 \mathrm{OE}-\mathrm{H}_{2} \mathrm{O}+\mathrm{Na}^{+}$ & 386.907 \\
\hline 30 & 393.961 & 31.3 & $\mathrm{H}_{3} \mathrm{BO}_{3}+7 \mathrm{OE}+\mathrm{Na}^{+}$ & 393.178 \\
\hline 41 & 414.240 & 5.1 & $\mathrm{H}_{3} \mathrm{BO}_{3}+8 \mathrm{OE}$ & 414.240 \\
\hline 42 & 418.268 & 8.1 & $\mathrm{H}_{3} \mathrm{BO}_{3}+4 \mathrm{OE}-\mathrm{H}_{2} \mathrm{O}+\mathrm{Au}$ & 416.987 \\
\hline \multirow[t]{2}{*}{43} & \multirow[t]{2}{*}{431.130} & \multirow[t]{2}{*}{5.6} & $\mathrm{Mel}+6 \mathrm{OE}+\mathrm{H}_{2} \mathrm{O}+\mathrm{Na}^{+}$ & 431.433 \\
\hline & & & $\mathrm{MDB}+4 \mathrm{OE}-\mathrm{H}_{2} \mathrm{O}+\mathrm{Na}^{+}$ & 430.958 \\
\hline 44 & 442.291 & 8.0 & $\mathrm{MEL}+8 \mathrm{OE}-2 \mathrm{H}_{2} \mathrm{O}$ & 442.501 \\
\hline \multirow[t]{2}{*}{45} & \multirow[t]{2}{*}{458.286} & \multirow[t]{2}{*}{7.6} & $\mathrm{H}_{3} \mathrm{BO}_{3}+9 \mathrm{OE}$ & 458.291 \\
\hline & & & $\mathrm{MEL}+7 \mathrm{OE}+\mathrm{Na}^{+}$ & 457.469 \\
\hline 46 & 462.290 & 8.2 & $\mathrm{H}_{3} \mathrm{BO}_{3}+5 \mathrm{OE}-\mathrm{H}_{2} \mathrm{O}+\mathrm{Au}$ & 461.038 \\
\hline 47 & 534.295 & 30.7 & $\mathrm{MDB}+6 \mathrm{OE}-\mathrm{H}_{2} \mathrm{O}+\mathrm{K}^{+}$ & 533.220 \\
\hline 48 & 590.938 & 29.8 & $\mathrm{H}_{3} \mathrm{BO}_{3}+12 \mathrm{OE}+\mathrm{H}^{+}$ & 591.452 \\
\hline 49 & 732.257 & 9.4 & $\mathrm{MEL}+15 \mathrm{OE}-3 \mathrm{H}_{2} \mathrm{O}$ & 732.843 \\
\hline 50 & 928.236 & 12.3 & $\mathrm{MEL}+19 \mathrm{OE}-2 \mathrm{H}_{2} \mathrm{O}+\mathrm{H}^{+}$ & 928.070 \\
\hline
\end{tabular}

$O E$ Oxyethylene groups, $M E L$ Structure from melamine

\section{Results and discussion}

MDB is the substrate easy to obtain. It precipitated upon cooling of hot mixture of melamine and boric acid. The ratio of Mel: $\mathrm{H}_{3} \mathrm{BO}_{3}$ in isolated product was $1: 2$, which as demonstrated by elemental analysis: $14.71 \% \mathrm{C}, 4.73 \% \mathrm{H}, 33.82 \% \mathrm{~N}$,
$8.36 \%$ B vs calculated: $14.40 \% \mathrm{C}, 4.80 \% \mathrm{H}, 33.60 \% \mathrm{~N}$, $8.80 \%$ B. This product was hydroxyalkylated with EC. The synthesis aimed at oligoetherols of appropriate viscosity enabling homogenization with typical isocyanates, commonly used for synthesis of PUFs. Suitable product was obtained from the reaction mixture $\mathrm{MDB}: \mathrm{EC}=1: 22$ as follows:

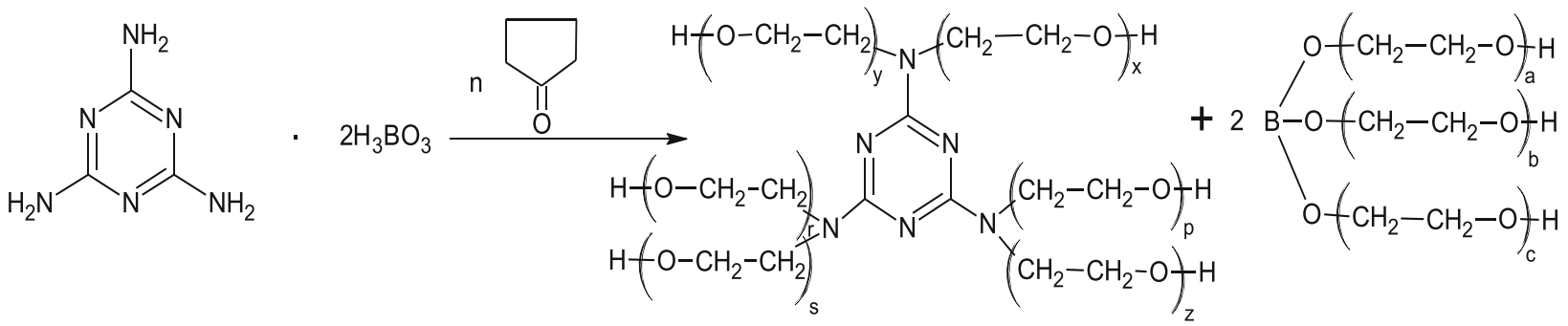

where:

$\mathrm{a}, \mathrm{b}, \mathrm{c}, \mathrm{p}, \mathrm{r}, \mathrm{s}, \mathrm{x}, \mathrm{y}, \mathrm{z}$ number of oxyalkylene units

$a+b+c+p+r+s+x+y+z=n$
By elemental analysis we found: $45.98 \% \mathrm{C}, 8.43 \% \mathrm{H}$, $6.64 \% \mathrm{~N}$, and $1.70 \% \mathrm{~B}$, which corroborate well with calculated $46.30 \% \mathrm{C}, 8.21 \% \mathrm{H}, 6,90 \% \mathrm{~N}$, and $1,81 \% \mathrm{~B}$ for MDB:EC $=1: 22$ product. The progress of reaction was controlled by IR of substrates and formed semiproducts and products. In the IR spectrum of MDB (Fig. 1) the broad band in the $3400-2500 \mathrm{~cm}^{-1}$ region belong to overlapping valence 
a

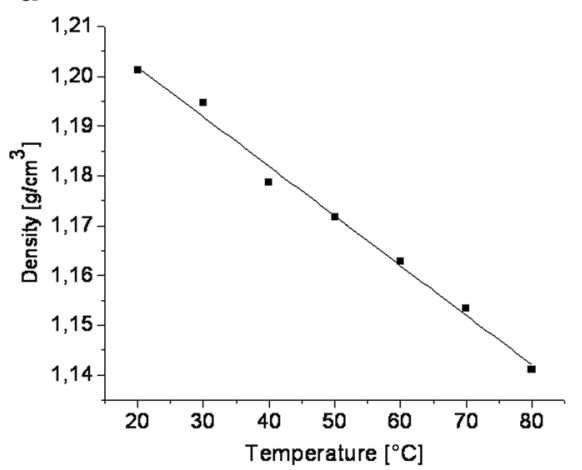

b

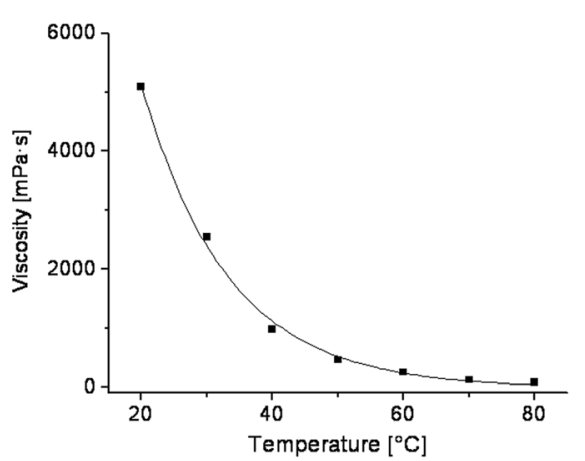

C

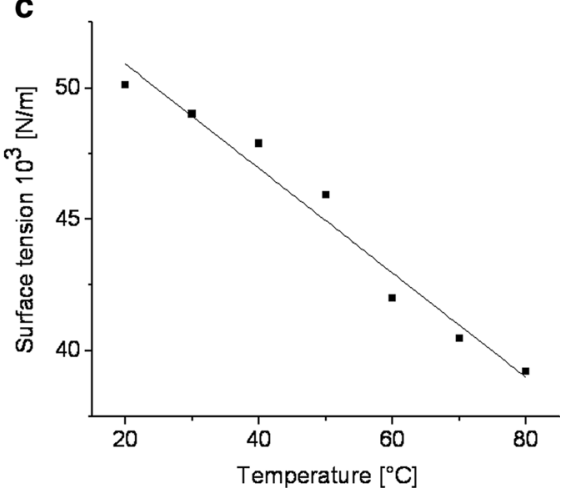

Fig. 4 Change of density $\mathbf{a}$, viscosity $\mathbf{b}$ and surface tension $\mathbf{c}$ of oligoetherol vs tempe-rature

vibrations of hydroxyl and amine groups, presumably interacting via hydrogen bonds. The characteristic bands in the $1600-550 \mathrm{~cm}^{-1}$ region from MEL and boric acid at were observed. Namely the band at $1451 \mathrm{~cm}^{-1}$ from valence B-O was observe as well as series of bands at: 1275,1235 , and $1126 \mathrm{~cm}^{-1}$ corresponding to $\mathrm{B}-\mathrm{O}-\mathrm{H}$ group.

The B-O stretching vibration bands were found in 898 , $873,694,597$, and $539 \mathrm{~cm}^{-1}$. The bands at $1492,805,745$, and $722 \mathrm{~cm}^{-1}$ were attributed to $1,3,5$-triazine ring vibrations [20]. The valence vibration band from $-\mathrm{NH}_{2}$ group disappeared totally in the spectrum of the oligoetherol (Fig. 2); instead it is replaced by hydroxyl group band (centered at $\left.3342 \mathrm{~cm}^{-1}\right)$ and methylene group band $\left(2866 \mathrm{~cm}^{-1}\right)$. Also the deformation band of $-\mathrm{NH}_{2}$ within 1660 to $1570 \mathrm{~cm}^{-1}$ is no longer present in the IR spectrum of oligoetherol. The presence of $\mathrm{B}-\mathrm{O}$ bond in the product was confirmed by the presence of the band at $1453-1413 \mathrm{~cm}^{-1}$. In IR spectrum of oligoetherol the bands at $1118 \mathrm{~cm}^{-1}$ was attributed to hydroxyl group, the ether C-O-C band was found at $1056 \mathrm{~cm}^{-1}$, while series of 1,3,5-triazine ring vibrations were observed at 898, $873,694 \mathrm{~cm}^{-1}$.
The ${ }^{1} \mathrm{H}-\mathrm{NMR}$ spectrum of MDB there are two signals from amine group protons, centered at $6.45 \mathrm{ppm}$ and low intensity one at $6.55 \mathrm{ppm}$ due to presence of protonated and not-protonated amine groups. In the ${ }^{1} \mathrm{H}-\mathrm{NMR}$ spectrum of oligoetherol (Fig. 3) the methylene group proton signals are located at $3.38-3.58 \mathrm{ppm}$. The hydroxyl protons resonate at $3.90 \mathrm{ppm}$ and $4.28 \mathrm{ppm}$; identified by selective deuteration with $\mathrm{D}_{2} \mathrm{O}$. Low intensity signal at $5.95 \mathrm{ppm}$ indicated the presence of trace amount of unreacted amine groups from MEL.

The structure of obtained oligoetherol can be deduced from MALDI-ToF spectra. At the MS spectrum of oligoetherol the molecular ion peaks from trace amount of substrates could be observed (Table 1, lines 2 and 3). The characteristic series of peaks enabled us to draw the conclusion that DBM can react with $\mathrm{EC}$ at $1-4 \mathrm{~mol} / \mathrm{mol}$ of adduct stochiometry (Table 1 , lines eg.: $30,34,39,43,47)$. Also the peaks corresponding to the products of reaction between boric acid with EC (Table 1, lines eg. 1, 3, 4, 5, 6, 8, 10,11, 13,14) and MEL with EC (Table 1, lines eg. 4, 7, 13, 17, 25, 32, 36) are present. From the MALDI -ToF we have concluded that at the mixture of

Table 2 The influence of composition on foaming process

\begin{tabular}{|c|c|c|c|c|c|c|c|c|}
\hline \multirow[t]{2}{*}{ Composition No } & \multicolumn{3}{|c|}{$\begin{array}{l}\text { Composition }[\mathrm{g} / 100 \mathrm{~g} \\
\text { of oligoetherols] }\end{array}$} & \multirow[t]{2}{*}{ Isocyanate index } & \multicolumn{3}{|l|}{ Foaming process } & \multirow[t]{2}{*}{$\begin{array}{l}\text { Characteristics of foam } \\
\text { immediately after formation }\end{array}$} \\
\hline & pMDI & TEA & Silicone & & Cream time $[\mathrm{s}]$ & Rise time $[\mathrm{s}]$ & Tack free time $[\mathrm{s}]$ & \\
\hline 1 & 200 & 1.3 & 2.3 & 1.4 & 24 & 10 & immediately & groowing too fast, \\
\hline 2 & 200 & 0.5 & 2.7 & 1.4 & 31 & 46 & immediately & as above, low shrinkage \\
\hline 3 & 150 & 0.3 & 2.7 & 1.0 & 23 & 17 & immediately & as above, low shrinkage \\
\hline 4 & 200 & 0.3 & 2.7 & 1.4 & 24 & 11 & immediately & regular pores \\
\hline $5^{*}$ & 200 & 0.3 & 3.1 & 1.4 & 24 & 9 & immediately & regular pores \\
\hline 6 & 200 & 0.1 & 3.1 & 1.4 & 20 & 10 & immediately & regular pores \\
\hline
\end{tabular}

Water was introduced into the reaction mixture at the level of $6 \mathrm{~g} / 100 \mathrm{~g}$ of oligoetherol

*Optimal compositions whose properties were tested

TEA Triethylamine - catalyst

pMDI Polymeric diphenylmethane diisocyanate 
Table 3 Some properties of polyurethane foam

\begin{tabular}{|c|c|c|c|c|c|c|c|c|c|c|c|}
\hline \multirow[t]{3}{*}{ Foam } & \multirow[t]{3}{*}{ Density $\left[\mathrm{kg} / \mathrm{m}^{3}\right]$} & \multicolumn{3}{|c|}{$\begin{array}{l}\text { Absorption of water } \\
{[\% \text { mas.] after }}\end{array}$} & \multicolumn{6}{|c|}{ Dimensional Stability [\%] in temperature $150{ }^{\circ} \mathrm{C}$} & \multirow[t]{3}{*}{$\begin{array}{l}\text { Heat conductance } \\
\text { coefficient }[\mathrm{W} / \mathrm{m} \cdot \mathrm{K}]\end{array}$} \\
\hline & & \multirow[t]{2}{*}{$5 \mathrm{~min}$} & \multirow[t]{2}{*}{$3 \mathrm{~h}$} & \multirow[t]{2}{*}{$24 \mathrm{~h}$} & \multicolumn{2}{|c|}{ Length change $[\%]$} & \multicolumn{2}{|c|}{ Width change $[\%]$} & \multicolumn{2}{|c|}{ Hight change $[\%]$} & \\
\hline & & & & & $20 \mathrm{~h}$ & $40 \mathrm{~h}$ & $20 \mathrm{~h}$ & $40 \mathrm{~h}$ & $20 \mathrm{~h}$ & $40 \mathrm{~h}$ & \\
\hline before exposition & 76.8 & 2.92 & 6.28 & 14.53 & -0.31 & -0.46 & -0.25 & -0.54 & -0.70 & -1.27 & 0.0375 \\
\hline after exposition in $150^{\circ} \mathrm{C}$ & 74.5 & 2.01 & 3.99 & 5.41 & - & - & - & - & - & - & 0.0387 \\
\hline after exposition in $175^{\circ} \mathrm{C}$ & 84.7 & 1.84 & 3.01 & 7.71 & - & - & - & - & - & - & 0.0801 \\
\hline
\end{tabular}

variable level of hydroxyalkylation products is obtained depending on the reagents molar ratio. Another characteristic feature was the series of peaks different by $\mathrm{M} / \mathrm{z}$ corresponding to mass of water was obtained, presumably due to dehydration of oligoetherols at high temperature (Table 1, lines eg. 30, 32, $33,36,37,38$ ) leading eventually to the presence of small percentage of unsaturated structures.

The oligoetherol has been studied by gas chromatography in order to determine the percentage of consecutive products formed upon reaction of EC with water. Water was released from products of hydroxyalkylation. The consecutive products could be formed by reaction of EC with water or with

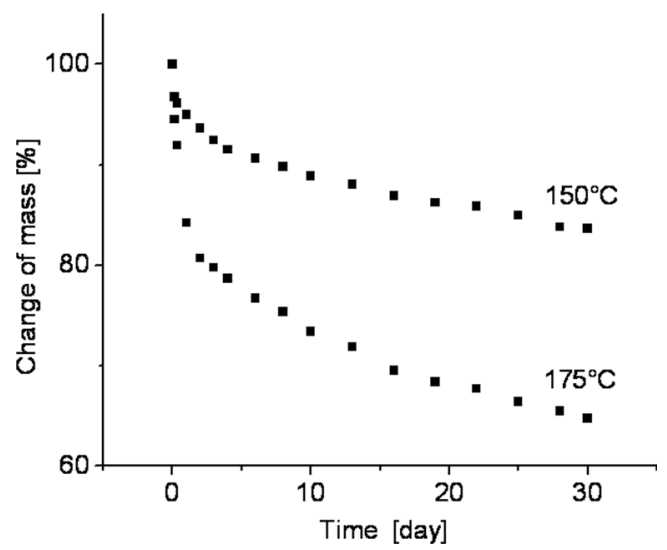

Fig. 5 Thermal stability of the polyurethane foam as the mass loss after heating at high temperature ethylene glycol. For comparative purpose we have recorded the chromatograms for the reference glycols (Experimental, Analytical methods). It has been found that only ethylene glycol was present in oligoetherol at the level of 1.3 mass $\%$ ) and no consecutive products were present. Thus we have concluded that involvement of dehydration accompanying hydroxyalkylation process is negligible. The presence of small amount of ethylene glycol in the product was also confirmed by slightly higher value of $\mathrm{HN}$, which was $619 \mathrm{mg} \mathrm{KOH} / \mathrm{g}$, while the calculated value for I was $573 \mathrm{mg} \mathrm{KOH} / \mathrm{g}$.

Some physical properties of the oligoetherol, like density, viscosity, and surface tension were determined (Fig. 4). It has been found that temperature dependence of these properties is typical. Thus, the viscosity and surface tension are within the range for oligoetherols used for fabrication of PUFs. Refraction index at $20^{\circ} \mathrm{C}$ was 1.4836 .

Further, the obtained oligoetherol was used to obtain PUFs. The optimization of isocyanate showed that the best PUFs were obtained when the molar ratio of isocyanate to hydroxyl groups was 1.4 (Table 2). Optimization of water in foaming composition indicated that $2-3 \%$ water led to very low foaming. Rigid PUFs, with regular pores were obtained with $6 \%$ water in relation to mass of oligoetherol. The amount of catalyst within $0.1-$ $0.5 \%$ did not influence the quality of PUFs. In case of $1.3 \%$ triethylamine catalyst fast grow of PUF was noticed accompanied with exothermic effect. It has been noticed that cream time and grow time depend slightly on amount of catalyst. For

Table 4 Thermal stability, compressive strength and flame properties of foams

\begin{tabular}{lllllll}
\hline Foam & $\begin{array}{l}\text { Mass loss in weight } \\
\% \text { after exposure for } \\
\text { one month }\end{array}$ & $\begin{array}{l}\text { Compressive } \\
\text { strength [MPa }]\end{array}$ & $\begin{array}{l}\text { Change of compressive } \\
\text { strength in [\%] }\end{array}$ & $\begin{array}{l}\text { Flame zone } \\
{[\mathrm{mm}]}\end{array}$ & $\begin{array}{l}\text { Flame rate } \\
{[\mathrm{mm} / \mathrm{s}]}\end{array}$ & $\begin{array}{l}\text { Mass loss upon } \\
\text { flaming [\%] }\end{array}$ \\
\hline before exposure & 0.0 & 0.268 & 0.0 & 49 & 0.5 & 15.9 \\
after exposure in $150^{\circ} \mathrm{C}$ & 16.3 & 0.458 & +70.9 & $0.0^{*}$ & 0.0 & - \\
after exposure in $175^{\circ} \mathrm{C}$ & 35.2 & 0.309 & +15.3 & $0.0^{* *}$ & 0.0 & - \\
\hline
\end{tabular}

* Self-extinguising foam, goes out after removal flame source

*** Non-flammable in flame source - long-term (30 s) applying a flame does not change flammability 
Table 6 Comparison of flame properties of polyurethane foam with 1,3,5-triazine ring and boron obtained from various oligoetherols

\begin{tabular}{llll}
\hline $\begin{array}{l}\text { Foam obtained } \\
\text { from oligoetherol }\end{array}$ & $\begin{array}{l}\text { Flame zone } \\
{[\mathrm{mm}]}\end{array}$ & $\begin{array}{l}\text { Flame rate } \\
{[\mathrm{mm} / \mathrm{s}]}\end{array}$ & $\begin{array}{l}\text { Mass loss upon } \\
\text { flaming [\%] }\end{array}$ \\
\hline MDB: $\mathrm{EC}=1: 22$ & 49 & 0.5 & 15.9 \\
$\begin{array}{c}\text { HHEM: } \mathrm{H}_{3} \mathrm{BO}_{3}: \\
\quad \mathrm{EC}=1: 3: 15[21]\end{array}$ & 25 & 1.1 & 14.6 \\
$\begin{array}{c}\mathrm{HHEM}: \mathrm{H}_{3} \mathrm{BO}_{3}: \\
\quad 15 C=1: 4: 15[21]\end{array}$ & & 1.1 & 22.4 \\
$\begin{array}{c}\mathrm{HHEM}: \mathrm{H}_{3} \mathrm{BO}_{3}: \\
\text { EC }=1: 5: 22[21]\end{array}$ & 150 & 1.2 & 23.5 \\
\hline
\end{tabular}

optimized PUF the cream time and grow time were: 24 and $9 \mathrm{~s}$, respectively. The PUF dried immediately.

Optimized PUF was characterized by physical parameters. Its apparent density was ca $77 \mathrm{~kg} / \mathrm{m}^{3}$ (Table 3 , column 2), which is higher than those of other PUFs with 1,3,5-triazine ring and boron $\left(40.6-53.8 \mathrm{~kg} / \mathrm{m}^{3}\right)$ obtained previously in the reaction between obtained oligoetherols with $\mathrm{N}, \mathrm{N}, \mathrm{N}^{\prime} \mathrm{N}^{\prime}, \mathrm{N}^{\prime \prime}, \mathrm{N}^{\prime \prime}$-hexakis(2-hydroksyethyl)melamine (HHEM), boric acid, and alkylene carbonates [21]. At elevated temperature $\left(150{ }^{\circ} \mathrm{C}\right)$ the obtained PUF showed shrinkage not exceeding $1.3 \%$. Water uptake after $24 \mathrm{~h}$ was as high as $14 \%$, which is close to that of mentioned PUFs ${ }^{21}$. High water uptake was attributed to presence of boron in the structure of PUF. Heat conductance coefficient $(0.0375 \mathrm{~W} / \mathrm{m} \cdot \mathrm{K})$ was larger in comparison with typical rigid PUFs $(0.019-0.026 \mathrm{~W} / \mathrm{m} \cdot \mathrm{K})$ [12], which seems to be related to the higher water uptake. However, heat conductance coefficient for obtained PUF is close to those found for PUFs obtained from oligoetherols synthesized from HHEM, boric acid and alkylene carbonates [21]. After heat exposition at $150{ }^{\circ} \mathrm{C}$ the conductance coefficient did not change, while it increased considerably after exposition at $175{ }^{\circ} \mathrm{C}$ (Table 3). This was presumably related to PUF structural changes and involvement of sample carbonization.

Table 7 Elemental analysis of foam obtained from oligoetherol MDB: $\mathrm{EC}=1: 22$

\begin{tabular}{llll}
\hline Element & \multicolumn{3}{l}{ Content of elements [weight \%] } \\
\cline { 2 - 4 } & Before exposure & \multicolumn{2}{l}{ After exposure in } \\
\cline { 3 - 4 } & & $150^{\circ} \mathrm{C}$ & $175^{\circ} \mathrm{C}$ \\
\hline $\mathrm{C}$ & 61.66 & 63.76 & 62.91 \\
$\mathrm{H}$ & 5.71 & 4.77 & 3.64 \\
$\mathrm{~N}$ & 9.20 & 10.71 & 11.41 \\
\hline
\end{tabular}


Table 8 Thermal analysis of foam determined by dynamic analysis

\begin{tabular}{llllll}
\hline Foam & $\mathrm{T}_{5 \%}\left[{ }^{\circ} \mathrm{C}\right]$ & $\mathrm{T}_{10 \%}\left[{ }^{\circ} \mathrm{C}\right]$ & $\mathrm{T}_{25 \%}\left[{ }^{\circ} \mathrm{C}\right]$ & $\mathrm{T}_{50 \%}\left[{ }^{\circ} \mathrm{C}\right]$ & $\mathrm{T}_{\max }\left[{ }^{\circ} \mathrm{C}\right]$ \\
\hline before exposure & 164 & 230 & 263 & 309 & 280 \\
after exposure in $150^{\circ} \mathrm{C}$ & 251 & 279 & 334 & 489 & 320 \\
after exposure in $175^{\circ} \mathrm{C}$ & 73 & 284 & 426 & $>600$ & $260-450$ \\
\hline
\end{tabular}

Thermal resistance of PUF was determined by mass loss measurements at 150,175 , and $200{ }^{\circ} \mathrm{C}$ together with determination of mechanical properties. The continuous mass loss was observed during heating, the highest rate was noticed within first $24 \mathrm{~h}$ (Fig. 5). It is worthy to underline that PUF gained its compressive strength within 30 days of the test (Table 4, column 3). The mass loss after one month of exposition at $150{ }^{\circ} \mathrm{C}$ was ca. $16 \%$, while compressive strength increased by $70 \%$, while after exposure at $175^{\circ} \mathrm{C}$ the mass loss was $35 \%$ accompanied with increase of compressive strength by $15 \%$. At $200{ }^{\circ} \mathrm{C}$ the PUF was deformed. Thus, the PUF obtained here has similar thermal resistance (at $150^{\circ} \mathrm{C}$ ) or slightly lower (at $175^{\circ} \mathrm{C}$ ) than those obtained from HHEM-based oligoetherol, boric acid and alkylene carbonates, while it has considerably higher compressive strength than the PUFs obtained before. However the PUF obtained here is not resistance against thermal exposure at $200{ }^{\circ} \mathrm{C}$, while those obtained from oligoetherols with boron incorporated in oligoetherol chain were thermally resistant in such conditions (Table 5) [21].

The presence of boron in PUF resulted in decrease of flammability in comparison with mentioned PUFs. This is demonstrated by both decrease of flaming rate and mass loss upon combustion (Table 6). The obtained PUF is selfextinguishing; in horizontal test the flame reached merely $49 \mathrm{~mm}$ from the ignition start point, also the flaming rate is $0.5 \mathrm{~mm} / \mathrm{s}$, while best PUFs described in [9] show 1.1 to $2.2 \mathrm{~mm} / \mathrm{s}$ flaming rate and generally bigger mass loss upon combustion. After thermal exposure the PUFs described here maintain flaming only in flame source contact. Probably it is related to a structural conversion of PUF upon thermal exposition. The PUFs after 1 month exposure to $150{ }^{\circ} \mathrm{C}$ showed increased oxygen index from 21.2 to $21.5 \%$, while those annealed at $175{ }^{\circ} \mathrm{C}$ showed oxygen index as high as $43.5 \%$ (Table 4). This indicates inflammability of annealed PUFs. From elemental analysis (Table 7) one can find the increase of nitrogen percentage and decrease of hydrogen percentage. The composition and structural changes of annealed PUFs are related to additional crosslinking, observed already at $150{ }^{\circ} \mathrm{C}$. The annealed PUFs show increase of compressive strength. When thermal exposure is performed at $175{ }^{\circ} \mathrm{C}$, the carbonization occur and PUFs lose their regular pores and become heterogeneous material. These changes result also lowering of water uptake of annealed PUFs.

Dynamic thermal analysis of the optimized PUF indicated that not thermal exposure PUF started to decompose at ca $164{ }^{\circ} \mathrm{C}$, while the PUF annealed at $150{ }^{\circ} \mathrm{C}$ started to decompose at ca $250{ }^{\circ} \mathrm{C}$ (Table 8 , Fig. 6). However the PUF annealed at $175^{\circ} \mathrm{C}$ was already changed and showed $5 \%$ mass loss at $73^{\circ} \mathrm{C}$. Maximum decomposition rate for not thermal exposure PUF was observed at $280^{\circ} \mathrm{C}$, which increased to $320^{\circ} \mathrm{C}$ after

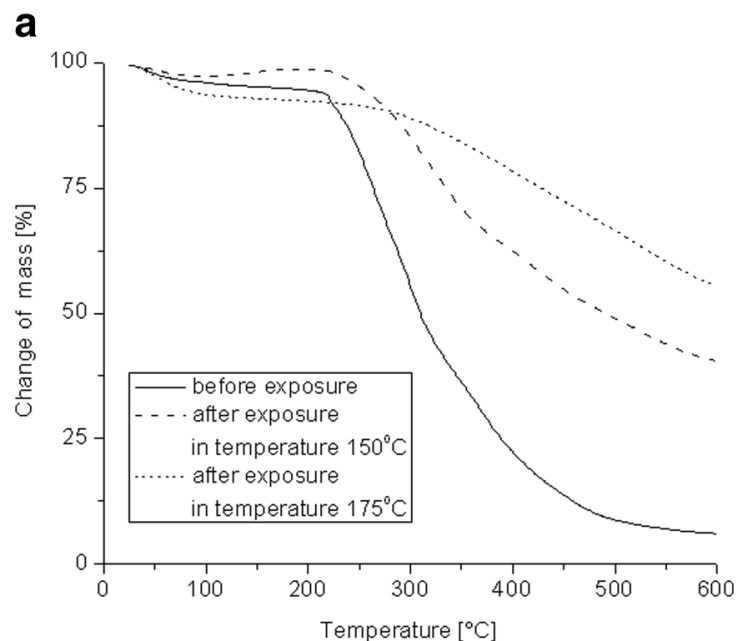

b

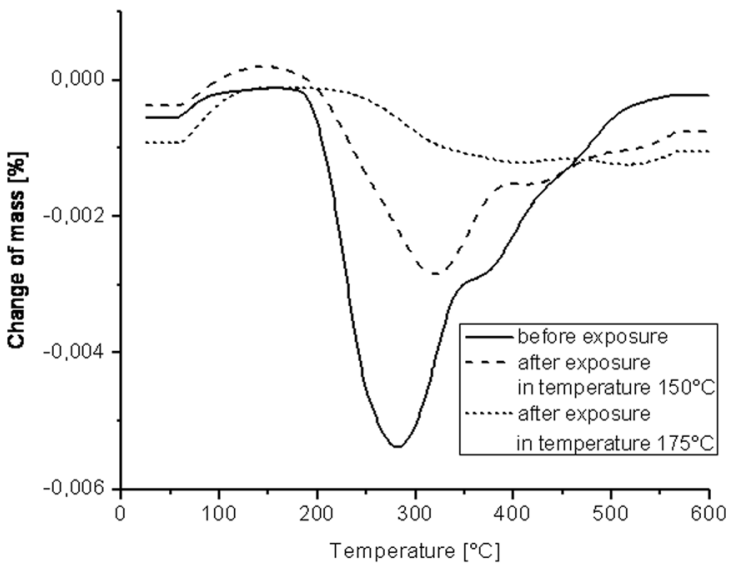

Fig. 6 Thermal analysis of foam No 5 according to the Table 2: mass change as a function of temperature a differential mass change as a function of temperature b 


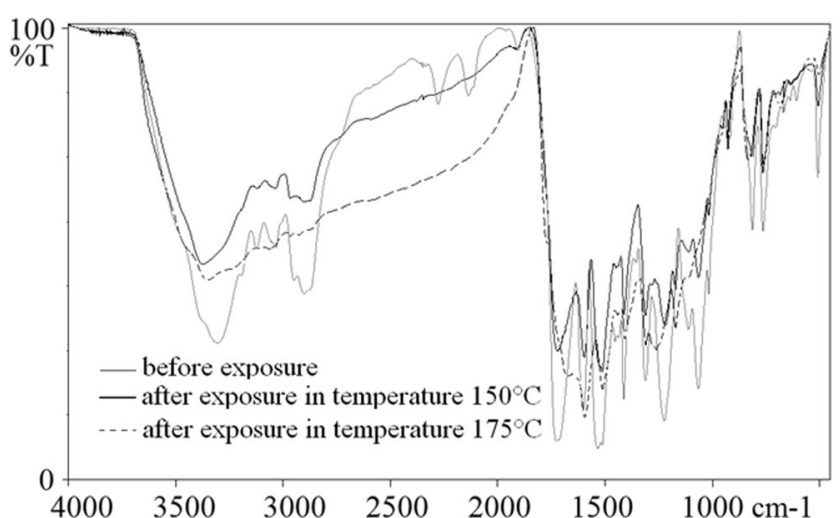

Fig. 7 The IR spectrum of the PUF No 5 (in Table 2) before thermal exposure and after exposure at $150{ }^{\circ} \mathrm{C}$ and $175^{\circ} \mathrm{C}$

annealing at $150{ }^{\circ} \mathrm{C}$. The PUF annealed at $175{ }^{\circ} \mathrm{C}$ decomposed in broad range of temperature: $260-450^{\circ} \mathrm{C}$.

The structural changes upon thermal exposure could be monitored by IR spectroscopy and microscopic morphological observation. In the IR spectrum of not thermal exposure PUF (Fig. 7) the band centered at $3302 \mathrm{~cm}^{-1}$ attributed to stretching vibration of $\mathrm{N}-\mathrm{H}$ bond, while $\mathrm{N}-\mathrm{H}$ bending vibration band was observed within $1600-1537 \mathrm{~cm}^{-1}$. The C-H stretching vibration band was observed at $3000-2900 \mathrm{~cm}^{-1}$. The presence of not reacted isocyanate groups is reflected by the band at $2276 \mathrm{~cm}^{-1}$, while the carbodiimide linkage has given the band centered at $2136 \mathrm{~cm}^{-1}$. Also the stretching vibration form $\mathrm{C}=\mathrm{O}$ at $1727 \mathrm{~cm}^{-1}$ is visible. However the band from carbodiimide group disappears upon thermal exposure, presumably due to oxidation. Similarly the band from isocyanate group vanishes upon annealing due to their reaction with hydroxyl groups of oligoetherol, leading to additional crosslinking. On the IR spectrum of PUF annealed at $150{ }^{\circ} \mathrm{C}$ the $\mathrm{C}-\mathrm{H}$ bands are well resolved; however after thermal exposure at $175{ }^{\circ} \mathrm{C}$ they are diffused. Based on digital images of PUFs (Fig. 8) one can notice that pore diameter before thermal exposure is ca $900 \mu \mathrm{m}$. Upon annealing the pores shrink and the apparent density increase (Table 3). For instance after one month thermal exposure at $150{ }^{\circ} \mathrm{C}$ the average pore diameter decreases to ca $200 \mu \mathrm{m}$, while annealing at $175^{\circ} \mathrm{C}$ results in $50-60 \mu \mathrm{m}$ pores (Figs. $7 \mathrm{~b}-\mathrm{d}$ ). These morphological changes explain the decrease of water absorption of annealed PUFs.

\section{Summary and conclusions}

Reaction melamine diborate with excess ethylene carbonate in presence of potassium carbonate catalyst resulted in formation of oligoetherol with incorporated 1,3,5 - triazine ring and boron atoms, designed especially for fabrication of rigid polyurethane foams. The optimized synthetic process requires molar ratio of reagents MDB: $\mathrm{EC}=1: 22,190-200^{\circ} \mathrm{C}$ temperature and $8-10 \mathrm{~h}$. The product is liquid resin of $5700 \mathrm{mPa} \cdot \mathrm{s}$
Fig. 8 Photo picture of PUF before thermal exposure, zoom $2.5 \mathrm{a}$, and after thermal exposure, at $150{ }^{\circ} \mathrm{C} \mathrm{b}, 175^{\circ} \mathrm{C} \mathbf{c}$, and the latter with 5.0 zoom d
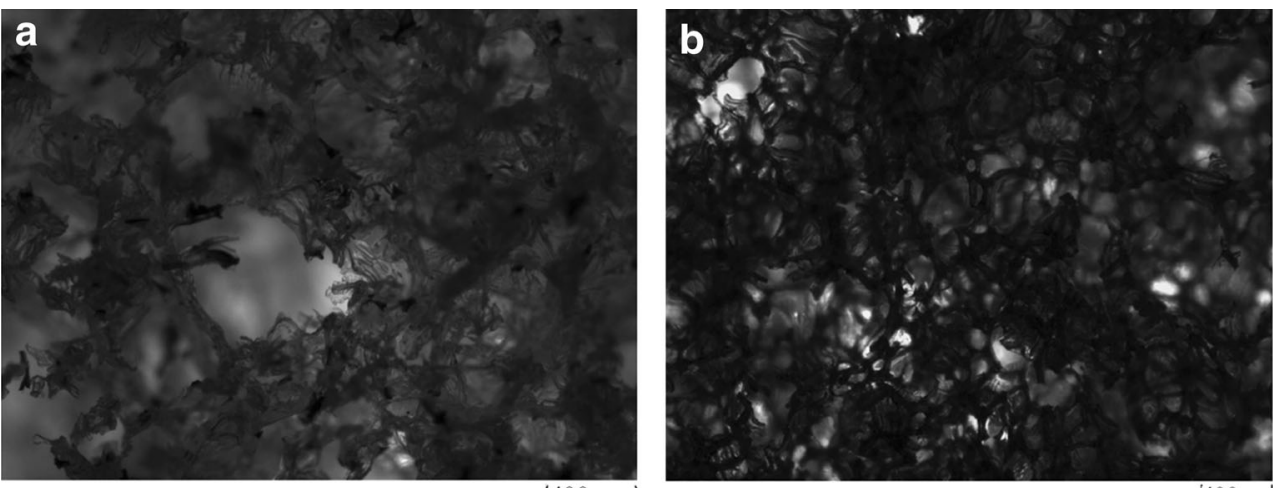

$|400 \mu \mathrm{m}|$
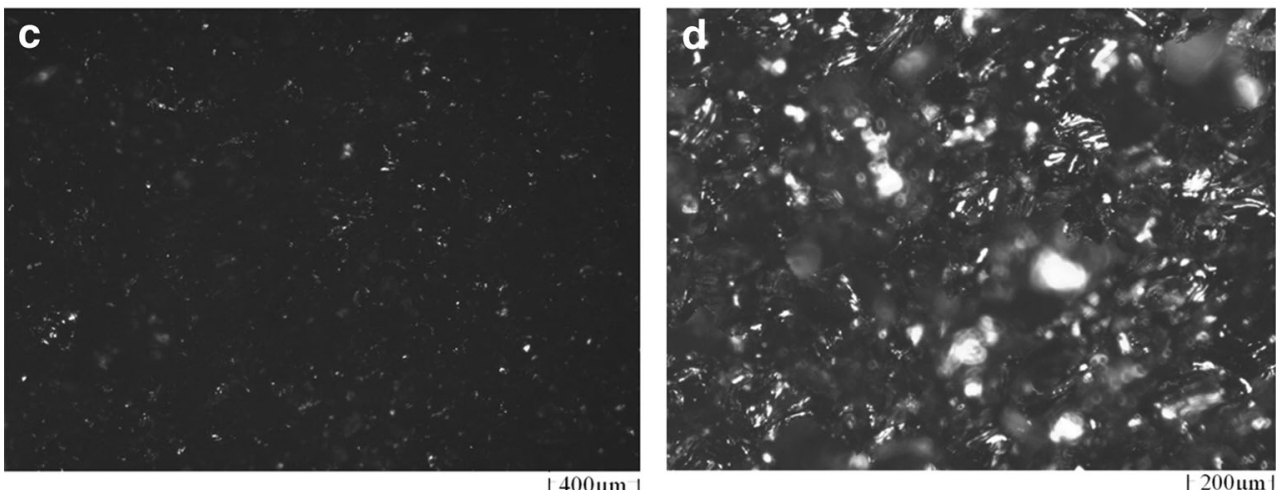
viscosity, $1.251 \mathrm{~g} / \mathrm{cm}^{3}$ density at $20^{\circ} \mathrm{C}$. The obtained PUF has similar properties as traditional rigid PUFs, except considerably higher thermal resistance and mechanical stability. It can stand long term heating at $175^{\circ} \mathrm{C}$. After thermal exposition at higher temperatures it shows increased compressive strength than not annealed one. The obtained PUF is selfextinguishing. Moreover, after thermal exposure the flammability of annealed PUF is further decreased; the flame ceases after removal of ignition source. This makes the obtained PUF a promising material. The solvent-free oligoetherol synthetic protocol, the choice of substrate (ethylene carbonate) can be considered as environmentally friendly process, eventually resulting in formation of self-extinguishing PUF.

\section{Compliance with ethical standards}

Conflict of interest The authors have declared no conflict of interest.

Open Access This article is distributed under the terms of the Creative Commons Attribution 4.0 International License (http:// creativecommons.org/licenses/by/4.0/), which permits unrestricted use, distribution, and reproduction in any medium, provided you give appropriate credit to the original author(s) and the source, provide a link to the Creative Commons license, and indicate if changes were made.

\section{References}

1. Lubczak J (2011) Polyhydroxyalkyl derivatives and polyetherols obtained from azacyclic compounds. Part I React Oxiranes Polimery 56:360-368

2. Lubczak J, Chmiel-Szukiewicz E, Duliban J, Głowacz-Czerwonka D, Lubczak R, Łuka-siewicz B, Zarzyka I, Łodyga A, Tyński P, Minda-Data D, Kozioł M, Majerczyk Z (2014) Polyurethane foams with 1,3,5-triazine ring of improved thermal stability. Przem Chem 10:1690-1697

3. Czupryński B, Paciorek-Sadowska J, Liszkowska J (2002) The effect of tri(1-chloro-3-etoxy-propane-2-ol) borate on the properties of rigid polyurethane-polyisocyanurate foams. Polimery 47:727-729

4. Czupryński B, Paciorek-Sadowska J, Liszkowska J (2006) Modifications of the rigid polyurethane-polyisocyanurate foams. J Appl Polym Sci 100:2020-2029
5. Czupryński B, Liszkowska J, Paciorek-Sadowska J (2006) Effect of selected boroorganic compounds on thermal and heat properties of rigid polyurethane-polyisocyanurate foams. J Appl Polym Sci 102: 768-771

6. Czupryński B, Paciorek-Sadowska J, Liszkowska J (2006) Studies on effect of tri(2- hydroxypropyl), tri(2-hydroxybutyl) and tri(hydroxythiodiethylene) borates on thermal and heat properties of rigid polyurethane-polyisocyanurate foams. Chin J Chem 24: 1796-1799

7. Paciorek-Sadowska J, Czupryński B (2006) New compounds for production of polyurethane foams. J Appl Polym Sci 102:5918-5926

8. Paciorek-Sadowska J, Czupryński B, Liszkowska J (2012) Firesafe polyurethanes modyfied with new antipyrene. Chem Aust 66:297-306

9. Łukasiewicz B, Lubczak J (2012) Oligoetherols and polyurethane foams with 1,3,5-triazine ring and boron. Polimery 57:819-829

10. Hull TR, Kandola BK (2009) Fire retardancy of polymers. Royal Society of Chemistry, Cambridge

11. Kijowska D, Wołowiec S, Lubczak J (2004) Kinetics and mechanism of initial steps of synthesis of polyetherols from melamine and ethylene carbonate. J Appl Polym Sci 93:294-300

12. Czupryński B (2004) Questions of chemistry and technology of polyurethanes. The Publishing House of the Academy of Bydgoszcz, Bydgoszcz

13. Broniewski T, Iwasiewicz A, Kapko J, Płaczek W (1967) Testing and evaluation of properties of plastics. WNT, Warsaw

14. Dryński T (1967) Laboratory of Physics. PWN, Warsaw Poland

15. Cellular Plastics and Rubbers. Determination of apparent (bulk) Density, Polish (European) Standards PN-EN ISO 845-2000. Ed. Polish Committee for Standardization

16. Cellular Plastics, Rigid. Determination of water absorption. Polish (European) standards PN-EN ISO 2896-1986. Ed. Polish Committee for Standardization

17. Cellular Plastics, Rigid. Test of dimensional stability. Polish (European) standards PN-EN ISO 2796-1986. Ed. Polish Committee for Standardization

18. Cellular Plastics, Compression test for rigid materials. Polish (European) standards PN- EN ISO 844-1978, Ed. Polish Committee for Standardization

19. Flexible Cellular polymeric Materials - Laboratory Characteristics of small specimens Subject to a small Flame. Polish (European) Standards PN-EN ISO 3582-2002. Ed. Polish Committee for Standardization

20. Panicker CY, Varghese HT, John A, Philip D, Nogueira HI (2002) Vibrational spectra of melamine diborate. Spectrochim Acta A 58: $1545-1551$ 